\title{
The Predictive Power of Leadership to the Perception of School Trust"
}

\author{
Emine Babaoğlan \\ Department of Educational Sciences, Faculty of Education, Bozok Üniversitesi, Turkey
}

Copyright $(2016$ by authors, all rights reserved. Authors agree that this article remains permanently open access under the terms of the Creative Commons Attribution License 4.0 International License

\begin{abstract}
The leadership of school principal and trust to school is important organizational variable for pleasure of school stakeholders and effectiveness of them. In this research these two variables are inquired according to school principal and vice principal perception. The purpose of this research is to determine predictive power of leadership to the perception of trust to school. This research is descriptive and quantitative study. In this research relational screening research method was used. In this research data were collected by two scales. The first scale is Leadership Behavior Questionnaire which was developed by Ekvall \& Arvonen and which was adapted into Turkish by Tengilimoğlu. The one-dimensional leadership scale consists of 36 statements. The second scale is to measure the principals' perception of organizational trust in elementary and secondary schools. "Omnibus T Scale" was used in this study. It was developed by Hoy and Tschannen-Moran and adapted into Turkish by Özer, Demirtaş, Üstüner and Cömert. The scale consists of 20 statements. The data were analyzed with descriptive and regression analysis. The research results demonstrate that the principals' and vice principals' perceptions of leadership behaviors of the school principals were at a very high level. Also, while the teachers' perception of trust in colleagues was high level, teachers' perception of trust in principal and trust in students and parents were at very high level. It was revealed that there was a meaningful relationship between the primary and secondary school principals' and vice principals' perception of leadership behaviors and their perception of trust in principal. Also it is found that the relationship between the primary and secondary school principals' and vice principals' perception of leadership behaviors and perception of trust in colleagues is positive and low level. Finally it is found that the relationship between the primary and secondary school principals' and vice principals' perception of leadership behaviors and perception of trust in students and parents were at a positive but low level.
\end{abstract}

Keywords Organizational Trust, Principal Leadership, Vice Principal, Trust to Principal, Trust to Teachers

\section{Introduction}

Trust in organizations is important variable effecting school effectiveness. Trust is defined various researches many times. According to Rousseau, Sitkin, Burt, and Camerer [36] trust is "the intention to accept vulnerability based upon positive expectations of the intentions or behavior of another". According to Mishra [30] trust is "one party's willingness to be vulnerable to another party based on the belief that the latter party is competent, open, concerned and reliable". Confidence, predictability and cooperation terms have been used in the same meaning with trust. Trust is a person's, a group's or an organization's confidence that another person, group or organization will protect the rights and benefits of everyone who voluntarily works or engages in an economic action together [22]. Trust can also mean the voluntary acceptance of a party that an important action will be performed by the other party as expected without being controlled. The factors that lead to trust are ability, benevolence, and integrity [28].

Organizational trust is one of the issues explored in Turkey. According to teacher, perception of trust in colleagues, and trust in school principals is at high level but their perception of trust in students and parents is at medium level [6]. It was determined that managers and officers did not have sufficient trust in each other, and also there was a meaningful difference between their perceptions [44]. It is showed that the organizational trust level within high schools was medium [32]. It was explored that honesty, competence, openness, loyalty, and consistency influenced trust in their subordinates [39].

Organizational trust is related to numerous variables in the organizations. Organizational trust and organizational commitment is related significantly [7]; [29]. Organizational trust was related both to organizational justice and to organizational citizenship behavior. Organizational trust has a significant effect on teachers to exhibit organizational citizenship behaviors [35]. There was relationship between trust and the openness of the organizational climate, cooperation among colleagues, professionalism, and authenticity and open and authentic behaviors of managers lead to higher employee trust [43]. Especially trust in the 
manager effects positively stakeholders' organizational commitment [38]. On the other hand insecure places produce negative behaviors [15].

One of the main variables effecting organizational trust is administrator behaviors and leadership. Because of behavior and leadership of administrator affecting numerous school outputs, a great number of researches have been conducted about school leadership. Edmonds [19] was made one of the first studies that emphasizing the significance of educational leaders and detected that the skills and competence of school principals were the fundamental factors which affecting the school performance in a positively. Leadership practices were important variable of effective schools [21]. Also a great number of researches have showed that effective educational leaders increased the student and school success [14]; [27]; [45]. Azodi [5] found that both the teachers and the school principals' leadership behaviors supported teachers' effectiveness. Arnold, Barling and Kelloway [3] determined that the transformational leadership increased commitment and team effectiveness. And also there was a positive relationship between leadership and culture [33].

Numerous leadership definitions have risen. According to Yukl [51] leadership is influencing the objectives and the strategies of the mission; the loyalty and compliance to achieve these objectives; and the group and the organizational culture. For Bass [10], leadership is a "group process", "a personality case (issue)", "a case of inducing compliance", "influencing experience", "exclusive behaviors", "a form of persuasion", "power relations", "a means for goal achievement", "an effect of interaction", "a differentiated role", "initiation of structure" and the various combinations of these definitions. Leadership is a process in which a person influences the group in order to achieve a common goal [31]. Leadership enhances the shared values and beliefs, sense of community and collaboration [45].

Leadership is one of the important issues researched in Turkey. According to Babaoğlan [6] the leadership behaviors of school principals are at high level. It was found that school principals considered the elements of transformational leadership significant; but they did not put them into practice [1]. Yılmaz and Altınkurt [50] determined that the teachers' perception pertaining to the leadership behaviors of the school principals was positive. In another research conducted in Turkey and the USA the leadership efficiency of school principals was at high level, according to the perceptions of both principals and teachers [9]. Altınkurt and Karaköse [2] found that although the ethical leadership behaviors of school principals were generally perceived positively, this perception was not so high. Moreover, the researchers revealed that almost half of the teachers did not think the school principals were tolerant and fair enough.

Between trust in a manager and the likelihood of an employee quitting a job is related [29]. There was a positive and strong relationship between trust and communication in administrator-officer relationships [44] and trust in a manager and the job employees' satisfaction [24]; [44]. Baird [8] examined the leadership behaviors or actions that were perceived to build or destroy feelings of trust. In this research it was concluded that trusted leaders behaves ethically, fairy and principled, valuing others, communicating openly, having high competency (acting with knowledge and experience, having clear purpose and vision), and consistency (stable and consistent).

Studies confirm that leadership behaviors affect the production outputs such as attitudes, efforts and working performance of the employee. Howell \& Frost [23] concluded that charismatic leadership behaviors were related to both the performance and the conformity to the mission, the leader and the group. Furthermore, it is understood that there was a meaningful relationship between the level of administrator's leadership behaviors that teachers observed and the level of teachers' job satisfaction[47].

Researches on leadership and trust have been conducted. For instance Babaoğlan [6] found that the relationship between teachers' leadership perception and their perception of trust in their principals was positive and significant at a high level. And also the relationship between teachers' perception of trust in colleagues and in students and parents was positive and significant at low level. Also it is found that there was a strong relationship between leadership behavior and organizational trust, in which the leadership behavior affected the other [34]. As a result of this impact, the followers feel trust and respect for the leader and get motivated to do more than what is expected of them [51]. For Childers [13], there was a link between transformational leadership and trust. In a similar way, Yeh [46] found that there was a meaningful and positive relationship between the leadership behaviors of managers and the workers' trust in the organization. Azodi [5] determined a meaningful relationship between leadership and the school principal's trust in the teachers, the students, and the families. Yilmaz [48] found that the school principals' ethical leadership skills had an impact on the organizational trust level in schools. Arnold, Barling and Kelloway's [3] research showed that transformational leadership increased trust and Laka-Mathebula [26] found that there was a relationship between the style of leadership and trust. Zhu, May and Avolio [52], and According to Arslantaş and Dursun [4], ethical leadership behavior had a direct impact on cognitive trust. For Y1lmaz [49], there was a high-level, positive and meaningful relationship between school principals' leadership behaviors and trust; furthermore, there was a meaningful relationship between school principals' supportive leadership behaviors and teachers' trust in their principals, colleagues, students and parents. Demir [18] revealed that the transformational leadership styles of the administrators have an impact on the organizational justice perception and the trust in the administrator had a positive role in this relationship. In their studies, Yllmaz and Altınkurt [50] found that teachers' perception of the organizational trust was positive. The researchers also revealed a high-level of positive relationship between the supportive leadership behaviors of the school principals and the teachers' trust in them; and the medium-level of positive 
relationship between the supportive leadership behaviors of the school principals and the teachers' trust perception of their colleagues and stakeholders.

The leadership of the organizational manager is considered to be significant in terms of the employees' trust in the organization. In other words, the behavioral patterns and the roles of the manager influence the employees' trust in the organization [46]. In the organization, the trust between the management and the employees is important. The mutual trust among the organizational members and between the management and their employees brings about communication and extraordinary success within the organization [11]. Podsakoff, MacKenzie, Moorman and Fetter [3] revealed that when employees had trust in their leaders, transformational leadership behavioral effected organizational citizenship behavior. On the basis of these findings, the researchers emphasized that as a result of transformational leadership behaviors, the performance increases more than what is expected. Korkmaz [25] found the transformational leadership of the high school principals influenced the trust and cooperative atmosphere within schools. According to Çelik [16] where it is dominated by bureaucratic control fear and distrust reveals.

The purpose of this research is to determine, from the primary and secondary school administrators' point of view, predictive power of leadership to the perception of trust to school. This research is descriptive and quantitative study. To reach this aim, the following questions are considered: 1.From the primary and secondary school administrators' perspective, what is the leadership and organizational trust level? 2. From the primary and secondary school administrators' perspective, how does the leadership of school principals affect the organizational trust perception of employee?

\section{Methodology}

This study employed a quantitative research approach. The correlational survey method was used in this research.

\subsection{Population and sample}

The participants of this research were school principals and vice principals working in the elementary and secondary schools located in the districts and villages of Burdur City of Turkey during 2009-2010 school years. Questionnaires were sent to all school principals and vice principals. Only 276 principals and vice principals completed the questionnaire for the research. These administrators are working in 196 schools throughout Burdur, 154 of which are primary and 42 are secondary. The 276 administrators aged from 26 to 63 . All administrator demographics were displayed in Table 1.

\subsection{Data collection tools}

The teachers' perception of their school principals' leadership behaviors was measured by the Leadership Behavior Questionnaire, which was developed by Ekvall and Arvonen [20] and adapted into Turkish by Tengilimoğlu [42]. The unidimensional questionnaire consists of 36 statements. Some of the statements are as follows: 1. Our schools' principal is friendly, 2. Our schools' principal listens to ideas and suggestions, and 3. Our schools' principal creates order. The scale is a 5-point Likert-type scale with the answers ranging as 1. Never, 2. Rarely, 3. Sometimes, 4. Mostly 5. Always. High scores indicate that the leadership behavior is perceived as positive while low scores imply the opposite. The alpha reliability coefficient of the Leadership Behavior Scale was found to be .98 .

Table 1. School principal and vice principal demographics

\begin{tabular}{clrr}
\hline Features of Principals & Number (\%) & Total (\%) \\
\hline \multirow{3}{*}{ Gender } & Female & $14(5,1 \%)$ & \\
& Male & $261(94.5 \%)$ & $276(100 \%)$ \\
& No response & $1(.4 \%)$ & \\
\hline \multirow{2}{*}{ Married } & Married & $264(95.7 \%)$ & \\
& Not Married & $12(4.3 \%)$ & $276(100 \%)$ \\
\hline \multirow{2}{*}{ Children } & Having Children & $259(93.8 \%)$ & \\
& Not Having Children & $15(5.4 \%)$ & $276(100 \%)$ \\
& No response & $2(.7 \%)$ & \\
\hline \multirow{2}{*}{ Branch of } & Classroom Teacher & $116(42 \%)$ & \\
Teacher & Social Since, History, Geography teacher & $33(12 \%)$ & $276(100 \%)$ \\
& Religion Culture teacher & $22(8 \%)$ & \\
& Science, Technology, Physic, Chemistry teacher & $22(8 \%)$ & \\
& Teachers of Other Branch & $83(30 \%)$ & \\
\hline \multirow{2}{*}{ School Type } & Primary Schools & $169(61.2 \%)$ & $276(100 \%)$ \\
& Secondary Schools & $107(38.8 \%)$ & \\
\hline \multirow{2}{*}{ School } & Provincial center & $100(36.2 \%)$ & \\
Location & Town & $125(45.3 \%)$ & $276(100 \%)$ \\
& Village & $51(18.5 \%)$ & \\
\hline \multirow{2}{*}{ Graduation } & Bachelor's Degree & $232(84.1 \%)$ & \\
& Two-year Degree & $31(11.2 \%)$ & $276(100 \%)$ \\
& Masters or Ph.D. Degrees & $8(2.9 \%)$ & \\
& No response & $5(1.8 \%)$ & \\
\hline
\end{tabular}


To measure the principals' perception of organizational trust in elementary and secondary schools, Omnibus T Scale, was used in this study. It was developed by Hoy and Tschannen-Moran[53] and adapted into Turkish by Özer, Demirtaş, Üstüner, and Cömert [32]. The scale consists of 20 statements. The organizational trust scale consists of three sub-dimensions. Some examples of the sub-dimensions and the statements in the scale are as follows: Trust in colleagues: 1. Teachers in this school trust each other, 2. Teachers in this school typically look out for each other. Trust in students and parents: 1. Students in this school care about each other, 2. Parents in this school are reliable in their commitments. Trust in principal: 1 . Teachers in this school can rely on the principal. 2. Teachers in this school have faith in the integrity of the principal. If the working group has a high score on every dimension this means that the trust level is high while a low score indicates a low trust feeling. The scale is a 5-point Likert-type ranging from 1. Disagree, 2. Low Agree, 3. Mid Agree, 4. Mostly Agree, to 5. Strongly Agree. A high score on this scale means that the trust level is high, whereas a low score means the trust level is low. The alpha reliability coefficient of the trust in colleague dimension, one of the sub-dimensions of the organizational trust scale, was found to be .92; the alpha reliability coefficient of the trust in students and parents dimension was found to be .89; and the alpha reliability coefficient of the trust in principal dimension was found to be 89 .

The mean score for leadership behavior and trust are as follows: $1-1.79=$ Very low level; $1.80-2.59=$ Low level; $2.60-3.39=$ Medium level; $3.40-4.19=$ High level and 4.20 $-5.00=$ Very high level.

\subsection{Data analysis}

A simple linear regression analysis was carried out to identify how the leadership behaviors of school principals affect (predict) the "trust in colleagues", "trust in students and parents", and "trust in principal" perceptions of the teachers [12]. The IBM SPSS 20 software was used in research data analysis.

\section{Findings}

The descriptive analysis and regression analysis findings regarding the "leadership behaviors" of the school principals from the perspectives of primary and secondary school principals and vice principals; and principals and vice principals' perception about "trust in colleagues", "trust in student and parents" and "trust in principal" can be found in this section. The descriptive analysis is presented in Table 2.

As seen in Table 2, with respect to primary and secondary school principals' and vice principals' perception, the mean (average) of the leadership behaviors of the school principals is $(\overline{\mathrm{X}}=4.4128)$, the average of trust in colleagues is $(\overline{\mathrm{X}}=4.0393)$, the average of the trust in students and parents is $(\overline{\mathrm{X}}=4.3717)$, the average of trust in the school principal is $(\overline{\mathrm{X}}=4.3717)$. Considering the averages, with respect to principals' and vice principals' perception, the leadership behaviors of school principals were perceived to be at very high level, trust in student and parents and trust in school principals were also at very high level but perception of trust in colleagues was at high level.

The simple linear regression analysis, which was carried out to identify, with respect to principals' and vice principals' perception, the predictive power of the leadership behaviors of school principals over teachers' perception of "trust in colleagues," "trust in students and parents" and "trust in principal" is presented in Table 3.

Table 2. Descriptive statistics according to the perception of principal and vice principal

\begin{tabular}{lccc}
\hline & $\overline{\mathrm{X}} /$ Std.Error & Level & $\begin{array}{c}\text { Measurement Range Points } \\
\text { (Min-Max) }\end{array}$ \\
\hline Leadership Behavior & $4.4128 \pm .6067$ & Very high & $1.92-5.00$ \\
\hline Trust in Colleagues & $4.0393 \pm .7498$ & High level & $1.29-5.00$ \\
\hline Trust in student and parents & $4.3717 \pm .6527$ & Very high & $1.40-5.00$ \\
\hline Trust in principal & $4.3717 \pm .6527$ & Very high & $1.40-5.00$ \\
\hline
\end{tabular}

Table 3. The simple linear regression analysis, to identify the predictive power of the leadership behaviors of school principals over "trust in colleagues," "trust in students and parents" and "trust in school principal"

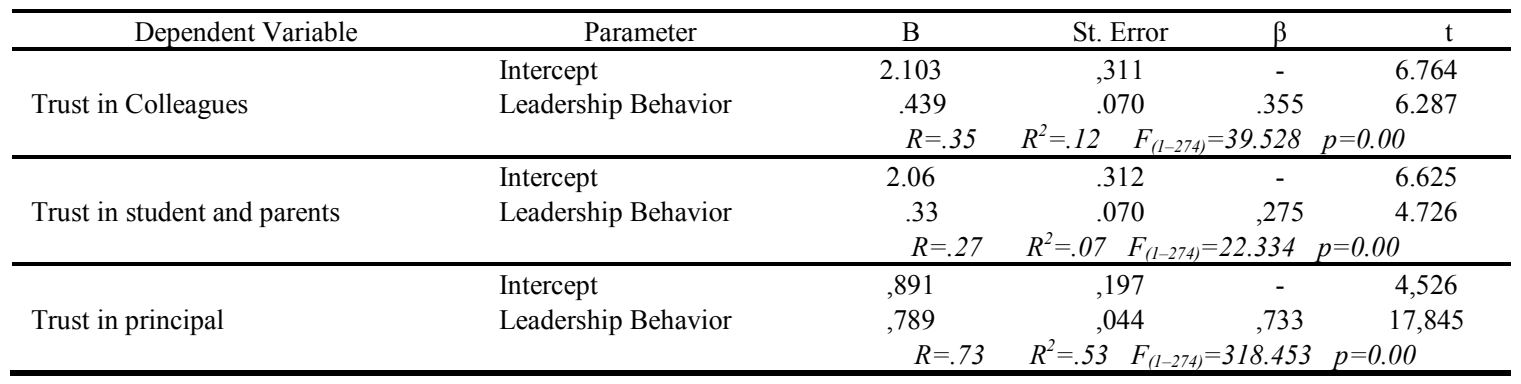


Since the $p$-value $(p=0.00)$ in the table, relating to the perception of "trust in colleagues," is smaller than .05 , it indicates that the $\mathrm{R}=.35$-value calculated for the relationship between the predictor and predicted variables in the regression model is significant. In other words, in this regression model, the linear relationship between the teachers' perception of "trust in colleagues" and the leadership behaviors of the school principals is at a statistically significant level.

Data analysis shows that there is a significant relationship between the leadership behaviors of the school principals and the teachers" perception of "trust in colleagues" $(\mathrm{R}=.35$ $\mathrm{R}^{2}=.12$ ), and the leadership behaviors of the school principals have a significant predictive power over teachers' trust in colleagues $\left(\mathrm{F}_{(1-274)}=39.528\right)$. The leadership behaviors of the school principals explain the $12 \%$ of the change in the teachers' perception of trust in colleagues. The significance test for the leadership behavior coefficient $(\mathrm{B}=.439)$, the predictor variable in the regression equation, shows that the leadership behavior is a significant predictor. According to these results, it can be said that, $12 \%$ of the total variance in the teachers' perception of "trust in colleagues" results from their opinions towards the "leadership behaviors" of the school principals. The regression equation for the teachers' perception of "trust in colleagues" is as follows:

Trust in Colleague $=(.439 \times$ Leadership Behavior $)+2.103$

The $p$-value $(p=0.00)$ in the table, relating to the perception of "trust in students and parents," is smaller than .05 indicating that the $\mathrm{R}=.27$-value calculated for the relationship between the predictor and predicted variables in the regression model is significant. In other words, in this regression model, the linear relationship between the teachers' perception of "trust in students and parents" and the leadership behaviors of the school principals is at a statistically significant level.

It is found that there is a significant relationship between the leadership behaviors of the school principals and the teachers' perception of "trust in students and parents" ( $\mathrm{R}=.27$ $\mathrm{R}^{2}=.07$ ), and the leadership behaviors of the school principals have a meaningful predictive power over teachers' trust in students and parents $\left(\mathrm{F}_{(1-274)}=22.334\right)$. The leadership behaviors of the school principals explain the $7 \%$ of the change in the teachers' perception of trust in students and parents. The significance test for the leadership behavior coefficient $(\mathrm{B}=.33)$, the predictor variable in the regression equation, shows that the leadership behavior is a significant predictor. According to these results, it can be said that, $7 \%$ of the total variance in the teachers' perception of "trust in students and parents" results from their opinions towards the "leadership behaviors" of the school principals. The regression equation for the teachers' perception of "trust in students and parents" is as follows:

Trust in Students and Parents $=(.33 \times$ Leadership Behavior) +2.06

The fact that the $p$-value $(p=0.00)$ in the table, relating to the perception of "trust in principal," is smaller than .05 indicates that the $\mathrm{R}=.73$-value calculated for the relationship between the predictor and predicted variables in the regression model is significant. In other words, in this regression model, the linear relationship between the teachers' perception of "trust in principal" and the leadership behaviors of the school principals is at a statistically significant level.

It is seen that there is a meaningful relationship between the leadership behaviors of the school principals and perception of "trust in principal" $\left(\mathrm{R}=.73 \mathrm{R}^{2}=.53\right)$, and the leadership behaviors of the school principals have a meaningful predictive power over trust in principal $\left(F_{(1-274)}=318.453\right)$. The leadership behaviors of the school principals explain the $53 \%$ of the change in the perception of trust in their principals. The significance test for the leadership behavior coefficient $(\mathrm{B}=.789)$, the predictor variable in the regression equation, shows that the leadership behavior is a significant predictor. According to these results, it can be said that $53 \%$ of the total variance in the perception of "trust in principal" results from their opinions towards the "leadership behaviors" of the school principals. The regression equation for the teachers' perception of "trust in principal" is as follows:

Trust in Principal $=(.789 \times$ Leadership Behavior $)+.891$

It is concluded that there is a low-level relationship between school principals" "leadership behaviors" and "trust in colleagues" and "trust in students and parents". On the other hand the relationship between the school principals' "leadership behaviors" and teachers' perception of "trust in principal" is positive at a high significant level. The relationship at the highest level identified in the research is between the leadership of the school principals and "trust in principal." The relationship at the lowest level, on the other hand, is between the leadership of the school principals' and the perception of "trust in students and parents."

\section{Discussion and Conclusion}

The research results demonstrate that the principals' and vice principals' perceptions of leadership behaviors of the school principals were at a very high level. This result is parallel with previous research results [6]; [9]; [2]. Also, while the teachers' perception of trust in colleagues was high level, teachers' perception of trust in principal and trust in students and parents were at very high level. In the previous research Babaoğlan [6] according to teachers' perception of trust in colleagues, and trust in school principals is at high level but their perception of trust in students and parents is at medium level. On the other hand Özer, Demirtaş, Üstüner and Cömert, [32] found that the organizational trust level within high schools was medium.

It was revealed that there was a meaningful relationship between the primary and secondary school principals' and vice principals' perception of leadership behaviors and their perception of trust in principal. According to principals' and vice principals' perception, the leadership behaviors of the 
school principals had a medium predictive power on trust in school principal. It can be stated that $53 \%$ of the total variance in the perception of "trust in principal" results from their opinions towards the "leadership behaviors" of the school principals. This finding shows that if the leadership behaviors of the school principals are perceived to be more positive, the employees' perception of trust in principals will also increase to a medium level. This result is similar the previous results conducted by Babaoğlan, [6], Yılmaz [49] and Yilmaz and Altınkurt [50].

In this research, it is found that the relationship between the primary and secondary school principals' and vice principals' perception of leadership behaviors and perception of trust in colleagues is positive and low level. This finding indicates that if there is an increase in the leadership behaviors of the school principals, there will also be an increase, even if it is slight, in the employee perception of trust in their colleagues. Babaoğlan [6] was reached similar results in the research according to teacher perception. In that research, it is found that there is a positive at low level and meaningful relation between the teachers' leadership perception of their principals and their perception of trust in colleagues. Y1lmaz [49] and Y1lmaz and Altınkurt [50], who conducted a research in a similar topic, identified that there was a positive and medium-level relationship between the supportive leadership behaviors of the principals and teachers' perception of trust in colleagues and stakeholders.

Finally it is found that the relationship between the primary and secondary school principals' and vice principals' perception of leadership behaviors and perception of trust in students and parents were at a positive but low level. This finding signals that if there is an increase in the leadership behaviors of the school principals, there will also be a slightly increase, in the employees' perception of trust in students and parents. Babaoğlan [6] was reached similar results in the research. It is found that there is a positive at low level and meaningful relation between the teachers' leadership perception of their principals and their perception of trust in students and parents.

The findings of this study showed that while bettering school principals' leadership behaviors, employee trust to principal, colleagues and students raise. According to Baird [8] the leadership behaviors or actions were perceived to build or destroy feelings of trust. In this research trusted leaders behaves ethically, fairy and principled, valuing others, communicating openly, having high competency, acting with knowledge and experience, having clear purpose and vision, and behaving stable and consistent. According to research results trust in colleagues have the high correlations with teacher collaboration and supportive work environment [17]. While establishing positive relationships with people, it is easier to accept and support them [37].

This research is a quantitative research which used survey method. In later research over the relationship between the leadership of the school principals and organizational trust should be qualitative research. This qualitative research can use in-depth face to face interviews and exploring employees' what type of behaviors expect from the leader of organization. And further studies can be conducted researching the leadership behaviors or actions were perceived to build or destroy feelings of trust.

\section{Note}

*The abstract of this paper was presented at 2nd International Conference on Lifelong Learning and Leadership for All (ICLEL-16), in Liepaja on July, 21-23, 2016.

\section{REFERENCES}

[1] Akbaba Altun, S. (2003). İlköğretim okulu müdürlerinin dönüşümcü liderliğe verdikleri önem ve uygulama düzeyleri. İlköğretim Online, 2(1), 10-17.

[2] Altınkurt, Y., \& Karaköse, T. (2009). İlköğretim okulu müdürlerinin etik liderlik davranışlarına ilişkin öğretmen görüşleri. Dumlupınar Üniversitesi Sosyal Bilimler Dergisi, 24, 269-280.

[3] Arnold, K. A., Barling, J., \& Kelloway, E. K. (2001). Transformational leadership or the iron cage: Which predicts trust, commitment and team efficacy. Leadership \& Organization Development Journal, 22(7), 315-320.

[4] Arslantaş, C., \& Dursun, M. (2008). Etik liderlik davranışının yöneticiye duyulan güven ve psikolojik güçlendirme üzerindeki etkisinde etkileşim adaletinin dolaylı rolü. Anadolu Üniversitesi Sosyal Bilimler Dergisi, 8(1), 111-128.

[5] Azodi, D. S. (2006). Principal, leadership, trust and teacher efficacy. Unpublished doctoral dissertation, Sam Houston State University, USA.

[6] Babaoğlan, E. (2016a). Improving principal and teacher relationship: Predictive power of school principals' leadership with teachers' organizational trust perception. Educational Planning, 23(2), 7-17.

[7] Babaoğlan, E. (2016b). The predictive power of organizational trust to organizational commitment in elementary and high school teachers. Anthropologist, 24(1), 83-89.

[8] Baird, C. (2010). Leadership Behaviors That Build or Destroy Trust: A Narrative Case Study. Unpublished Doctoral dissertation. The University of North Carolina at Greensboro.

[9] Babaoğlan, E., \& Litchka, P. R. (2010). An examination of leadership competencies of school principals in Turkey and the United States. Education and Science, 35(158), 58-74.

[10] Bass, B. M. (1990). Bass \& Stogdill's handbook of leadership: theory, research, and managerial applications, 3rd. Ed., New York: The Free Press.

[11] Callaway, P. L. (2006). The relationship between organizational trust and job satisfaction: An analysis in the U.S. Federal Work Force. Unpublished doctoral dissertation, Capella University, USA. 
[12] Can, A. (2013). SPSS ile bilimsel araştırma sürecinde nicel veri analizi. Ankara: Pegem A Yayıncılık.

[13] Childers, W. H. (2009). Transformational leadership and its relationship to trust and behavioral integrity. Unpublished doctoral dissertation, Saybrook Graduate School and Research Center, USA.

[14] Cistone, P. J., \& Stevenson, J. M. (2000). Perspectives on the urban school principalship. Education \& Urban Society, 32(4), 435-442.

[15] Çelik, E. (2015a). Batı edebiyatında polisiye romanın gelişimi sürecinde düşünsel ve sosyal etkiler. Hacettepe Üniversitesi Sosyolojik Araştırmalar E-Dergisi, 1-14

[16] Çelik, E. (2015b). Distopik romanlarda toplumsal kurgu. Sosyoloji Araştırmaları Dergisi, 18(1), 57-79.

[17] Demir, K. (2015). The effect of organizational trust on the culture of teacher leadership in primary schools. Educational Sciences: Theory and Practice, 15(3), 621-634.

[18] Demir, N. (2008). Liderlik tarzının örgütsel adalet ile ilişkisi ve lidere olan güvenin bu ilişkideki rolü. Öneri, 8(30), 195-205.

[19] Edmonds, R. (1979). Effective schools for the urban poor. Educational Leadership, 37(1), 15-24.

[20] Ekvall, G., \& Arvonen, J. (1991). Change-centered leadership: An extension of the two-dimensional model. Scandinavian Journal of Management, 7(1), 17-26.

[21] Elliot, S. E. (2000). The relationship between teacher efficacy and principal leadership behaviors and teacher background variables in elementary schools. Unpublished doctoral dissertation, University of Connecticut.

[22] Hosmer, L. T. (1995). Trust: The connecting link between organizational theory and philosophical ethics. The Academy of Management Review, 20(2), 379-403.

[23] Howell, J. M., \& Frost, P. J. (1989). A laboratory study of charismatic leadership. Organizational Behavior and Human Decision Processes, 43, 243-269.

[24] Koç, H., \& Yazıcıoğlu, İ. (2011). Yöneticiye duyulan güven ile iş tatmini arasındaki ilişki: kamu ve özel sektör karşıllaştırması. Doğuş Üniversitesi Dergisi, 12(1), 46-57.

[25] Korkmaz, M. (2008). Okul müdürlerinin liderlik stilleri ile öğrenen örgüt özellikleri arasındaki ilişki üzerine nicel bir araştırma. Kuram ve Uygulamada Eğitim Yönetimi, 53, 75-98.

[26] Laka-Mathebula, M. R. (2004). Modeling the relationship between organizational commitment, leadership style, human resources management practices and organizational trust. Unpublished doctoral dissertation, University of Pretoria, South Africa.

[27] Marzano, R. J., Waters, T., \& McNulty, B. A. (2005). School leadership that works: from research to results, Alexandria, VA: Association for Supervision and Curriculum Development (ASCD).

[28] Mayer, R. C., Davis, J. H., \& Schoorman, F. D. (1995). An integrative model of organizational trust. The Academy of Management Review, 20, 709-734.

[29] Milligan, P. K. (2004). The impact of trust in leadership on officer commitment and intention to leave military service in the U.S. Air Force. Unpublished doctoral dissertation,
Capella University, USA.

[30] Mishra, A. K. (1996). Organizational responses to crisis: The centrality of trust. Kramer. In, M. Roderick \& T. Tyler, (Eds.), Trust in Organizations (pp. 261-287). Newbury Park, CA: Sage.

[31] Northouse, P. (2009). Leadership theory and practice. Thousand Oaks, CA: Sage.

[32] Özer, N., Demirtaş, H., Üstüner, M., \& Cömert, M. (2006). Ortaöğretim öğretmenlerinin örgütsel güven algıları. Ege Eğitim Dergisi, 7(1), 103-124.

[33] Parry, K., \& Proctor Thomson, S. B. (2003). Leadership, culture and performance: the case of the New Zealand public sector. Journal of Change Management, 3(4), 376-399.

[34] Podsakoff, P. M., MacKenzie, S. B., Moorman, R. H., \& Fetter, R. (1990). Transformational leader behaviors and their effects on followers' trust in leader, satisfaction, and organizational citizenship behaviors. Leadership Quarterly, $1(2), 107-142$.

[35] Polat, S., \& Celep, C. (2008). Ortaöğretim öğretmenlerinin örgütsel adalet, örgütsel güven, örgütsel vatandaşlık davranışlarına ilişkin algıları. Kuram ve Uygulamada Eğitim Yönetimi, 54, 307-331.

[36] Rousseau, D. M., Sitkinn, S. B., Burt, R. S., \& Camerer, C. (1998). Not so different after all: a cross discipline view of trust. Academy of Management Review, 23(3), 393-404.

[37] Salı, G. (2014). Okulöncesi dönem çocuklarında akran ilişkilerinin ve akran şiddetine maruz kalmanın çeşitli değișkenler açısından incelenmesi. Çukurova Üniversitesi Eğitim Fakültesi Dergisi, 43(2), 195-216.

[38] Sağlam Arı, G. (2003). Yöneticiye duyulan güven örgütsel bağl1lığ1 artırır mı? Gazi Üniversitesi Ticaret ve Turizm Eğitim Fakültesi Dergisi, 60(1), 121-148.

[39] Sağlam Arı, G., \& Güneri Tosunoğlu, N. (2011). Geleceğin yöneticileri astlarına güvende hangi özelliklere öncelik veriyor? Yönetim ve Ekonomi, 18(2), 85-103.

[40] Şişman, M. (2002). Öğretim liderliği. Ankara: PegemA Yayıncilık.

[41] Şişman, M., \& Turan, S. (2002). Eğitimde toplam kalite yönetimi. 2. Bask1, Ankara:PegemA Yayıncılık.

[42] Tengilimoğlu, D. (2005). Hizmet işletmelerinde liderlik davranışları ile iş doyumu arasındaki ilişsinin belirlenmesine yönelik bir araştırma. Ticaret ve Turizm Eğitim Fakültesi Dergisi, 1, 23-45.

[43] Tschannen-Moran, M., \& Hoy, W. (1998). Trust in schools: A conceptual and empirical analysis. Journal of Educational Administration, 36(4), 334-352.

[44] Uz, O. (2006). T. C. kamu sektöründe yönetici-yönetilen ilişkilerinde iletişim ve güven. Yayımlanmamış yüksek lisans tezi, Atılım Üniversitesi, İstanbul. Retrieved 14 February, 2014 from https://tez.yok.gov.tr/UlusalTezMerkezi/tarama.jsp

[45] Waters, J. T., Marzano, R. J., \& McNulty, B. A. (2004). Leadership that sparks learning. Educational Leadership, 61(7), 48-51.

[46] Yeh, T. (2007). Leadership behavior, organizational trust and 
organizational commitment among volunteers in Taiwanese nonprofit foundations. Unpublished doctoral dissertation, University of the Incarnate Word.

[47] Yılmaz, A., \& Ceylan, Ç. B. (2011). İlköğretim okul yöneticilerinin liderlik davranış düzeyleri ile öğretmenlerin iş doyumu ilişkisi. Kuram ve Uygulamada Eğitim Yönetimi, 17(2), 277-394

[48] Yılmaz, E. (2006). Okullardaki örgütsel güven düzeyinin okul yöneticilerinin etik liderlik özellikleri ve bazı değişkenler açısından incelenmesi. Unpublished doctoral dissertation tezi, Selçuk Üniversitesi, Konya. Retrieved 14 February, 2014 from https://tez.yok.gov.tr/UlusalTezMerkezi/tarama.jsp

[49] Yılmaz, K. (2004). İlköğretim okulu öğretmenlerinin görüşlerine göre okul yöneticilerinin liderlik davranışları ile okullardaki güven arasındaki ilişki. İnönü Üniversitesi Eğitim Fakültesi Dergisi, 5(8), 117-131.
[50] Yilmaz, K. ve Altınkurt, Y. (2012). Relationship between the leadership behaviors, organizational justice and organizational trust. Çukurova University Faculty of Education Journal, 41(1), 12-24.

[51] Yukl, G. (1989). Managerial leadership: A review of theory and research. Journal of Management, 15(2), 251-289.

[52] Zhu, W., May, D. R. \& Avolio, B. J. (2004). The impact of ethical leadership behavior on employee outcomes: the roles of psychological empowerment and authenticity. Journal of Leadership and Organizational Studies, 11(1), 16-26.

[53] Hoy, W. K., \& Tschannen-Moran, M. (2003). The conceptualization and measurement of faculty trust in schools: The omnibus T-Scale. In W. K. Hoy \& C. Miskel (Eds.), Studies in leading and organizing schools (pp. 181-208). Greenwich CT: Information Age. 